\title{
STRUCTURAL-FUNCTIONAL ANALYSIS OF ECOLOGICAL COMPETENCIES OF THE FUTURE BIOLOGY TEACHERS
}

\begin{abstract}
Maryna Khrolenko ${ }^{1}$
${ }^{1}$ Candidate of Pedagogical Sciences, Associate Professor, Associate Professor at the Department of Theory and methodics of teaching natural sciences Oleksandr Dovzhenko Hlukhiv National Pedagogical University, Hlukhiv, Ukraine, e-mail: marina.khrolenko@gmail/com, ORCID: https://orcid.org/0000-0002-2118-1977
\end{abstract}

\begin{abstract}
We analyzed the approaches to defining the structural components of the ecological competence of the future biology teachers. It was found out that the separation of a single conglomerate, which includes cognitive, motivational-value and activity components are common in the interpretation of the structure of the analyzed competence. The rest of the components regarding the name and sence varies depending on the context of the scientists' consideration of the problem, author's vision of the research concept, etc. Ecological competence of the future pedagogs is defined as the ability to realize the own potential in active and responsible way (knowledge of ecology, skills, experience) for successful professional activity in the spheres of ecological education and upbringing of the pupils; to acknowledge the own role and the responsibility in renewal, reserving the environment, "greening" the consciousness of the pupils; to perform ecologically efficient activity, to solve ecological tasks practically in the professional and household spheres according to the principles of the stated development gained ecological values, motives of interaction with nature, beliefs, ideals, etc. Ecological competence is considered as an integration formation, where each component is in mutual unity, conditionality with others has its own functional value. We reasoned the defining of the ecological competence functions of the students of the pedagogical specialties: coevolutionary-biosphere, educational, practical-regulatory, activity-normative, professionalorientation. We defined the structural components of the future biology teachers' ecological competence: knowledge-content, motivational-valuable, activity-technological, professionallyreflexive. The content, functions, interconnections of each component of the ecological competence were outlined. It was emphasized on the importance to take into account all the functional senses, interconnections of its structural constructs while the formation of mentioned personal quality. Underestimation of any component is going to influence the efficiency and the end result of the whole process.
\end{abstract}

Keywords: ecological competence, future biology teachers, structure, the components of the ecological competence, functions of the ecological competence.

JEL Classification: JEL IO; I20

Formulas: 1; fig.: 0; tabl.: 1; bibl.: 17

Introduction. A teacher of the $21^{\text {st }}$ century should become a person with a new ecological philosophy, new ecological culture based on the knowledge and respect for the principles of nature growth. This process should be started with formation of the ecological imperative as a necessary determinant of the evolutionary project of mankind that is able to organize balanced development of the human and nature [1]. Ecological competence is a vital component of the future teachers' ecological imperative. Ecological competence is the ability to realize the own potential in active and responsible way (knowledge of ecology, skills, experience) for successful professional activity in the spheres of ecological education and upbringing of the pupils; to acknowledge the own role and the responsibility in renewal, reserving the environment, "greening" the consciousness of the pupils; to perform the ecologically efficient activity, to solve ecological tasks practically in the professional and household 
spheres according to the principles of the stated development gained ecological values, motives of interaction with nature, beliefs, ideals, etc [2].

Ecological competence is an integrative creation, a set of certain components that are in mutual unity, conditionality and connection. At the same time, each component of the studied competence has its own features, sense and functional meaning. It is important to take into account all the functional senses, interconnections of its structural constructs while the formation of mentioned personal quality. Underestimation of any component is going to influence the efficiency and the end result of the whole process. Due to that, the research of structural and functional analysis of the future biology teachers' competence becomes actual.

Literature review. The scientific research of O. Hryniuk, D. Yermakov, O. Kolonkova, N. Kurylenko, S. Levkiv, H. Naidonova, O. Prutsakova, N. Pustovit, L. Rudenko, S. Shmaliei, etc. are aimed at the study of the structure of ecological competence of students of general secondary education. Component composition of the ecological competence of the future specialists of various specialties is studied by Ya. Absaliamova, Yu. Boichuk, O. Hurenkova, V. Lukianova, L. Lukianova, S. Lutkovska, O. Mateiuk, I. Munasypova-Motiash, A. Khrypunova. The issues raised in the work outline the importance of the study of the content, functional relationships of the structural components of the environmental competence of students of biological specialties (L. Tytarenko), future teachers of natural sciences (L. Nikitchenko, I. Siaska), future biology lecturers (N. Baiurko, Ya. Lohvinova), future biology teachers (I. Koreneva, S. Rudyshyn, V. Samilyk, Yu. Shapran).

Despite a significant contribution of the scientists to the research of the problem of the structure of the students' ecological competence, the research results of the state of its theoretical and practical level proves the necessity to continue scientific research in a certain direction.

Aims. The aim of the study is to clarify the component composition of the future biology teachers' ecological competence, to define the content, structural-functional correlations of its components based on the analysis of the study research of structure of environmental competence of an individual.

Methods of the research: content analysis of scientific research on the problem of structural organization of ecological competence of the individual, synthesis, generalization, systematization.

Results. The content of the ecological competence allows to define the components that the studied phenomenon consists of. Peculiarities, functional connections of the ecological competence components should be taken into account while the formation of the mentioned future teachers' feature. Therefore there is a need to outline the functions of ecological competence.

D. Yermakov emphasizes the multifunctionality of the pupils' ecological competence which outlines its general educational character. The scientist claims that for the proper understanding of ecological competence the important role play its functions such as: biosphere, methodological, integrative, systemic, cultural, social, prognostic, practical, value-based, the function of professional self-determination [3, p. 21]. While the study of the ecological competence of the pupils of general secondary 
education, N. Kurylenko distinguishes such functions of the studied competence: moral and ethical, hygienic, integrative systemic, social, prognostic, practical, economic, developmental, of professional self-determination [4, p. 33-34]. I. Siaska adds worldview-orientational, socio-cultural, socio-economic, practical-domestic, professional self-realization, public-educational functions to the ecological competence functions of the future natural sciences teachers. Such functions are gained while professional training [5, p. 167].

Summarizing, based on the analysis of the literature sources we outline such ecocompetence functions of the future biology teachers: coevolutionary-biosphere (provides for the actualization of ideas about the priority of coevolutionary development of society and the biosphere as an absolutely necessary condition for harmonization and comprehensive development of the global system of correlative relations «man-nature», preservation of life on Earth), educational (implementation of enhanced environmental education, development of environmental literacy, education of students), educational (provides for the activity of future teachers in the formation and development of students' responsible and caring attitude to the natural environment, awareness of the value of nature, compliance with norms and rules of rational use of nature, etc.), practical-regulatory (provides for the application future teacher of certain mechanisms of regulation of relations in the system «man-nature», approaches to solving environmental problems of various scales), activity-normative (implementation of active, ecologically safe activity according to the principles of sustainable development and norms of rational nature use, mastering of norms of ecologically competent behavior), professionally orientational (ability to form adequate ecological ideas of student youth, a system of skills, abilities and strategies of interaction with nature, development of their ecological competence, culture).

Analysis of the component composition of the studied skill proved the fact that most of the scientists distinguish knowledge and skills, values and motives, practical activity and behavior in the researched skill. In most cases, future biology teachers' ecological competence consists of several components (from 3 to 6). The systemforming base consists of such components as: cognitive (cognitive, cognitive, information-experiential), motivational-valuable (axiological), activity (activitybehavioral, operational, practical). The other components of the eco-competence differ but generally, they provide for the acknowledging and realization of ecologically aimed professional skills.

Besides all the mentioned components of the future biology teachers' ecological competence I. Siaska defines reflexive-evaluative component as well. The scientist sees a formation of the reflexive-evaluative component of the ecological competence in the ability to adjust their own behavior and activities in the environment, predict its consequences and be responsible for it on the basis of self-reflection, self-regulation and development of environmental self-awareness [6, p. 158].

While studying the formation characteristics of ecological competence of the future teachers of natural sciences while professional training L. Nikitchenko defines a creative component in the structure of eco-competence except for cognitive and activity ones. In the author's opinion, a creative component «is aimed at acknowledging 
a person as a part of nature, the ability to change positively through the formation of the internal ecological consciousness» [7, p. 222].

L. Lukianova defines the fourth normative component besided the three traditional ones. It provides for assimilation and implementation of a system of environmental norms, laws, regulations, rules on the activities and behavior of each individual as a citizen in general, and the specialist in particular [8].

Yu. Shapran defines motivational-valuable, cognitive-activity and personalreflexive component in the structure of the analyzed competence. We agree with the scientist regarding the importance of distinguishing of the personality-reflexive component of the future biology teachers' ecological competence as it is «a set of important personality's traits for environmental performance - cooperation, humanity, responsibility, communicative, empathy, optimism, emotional stability, reflection, etc.» $[9$, p. 322].

While studying the formation of the ecological competence of the students of biological specialties of universities, L. Tytarenko claims that a person's ecological competence is based on the combination of information-experience, motivationalvaluable, behavioral-activity components. The scientist pays attention to integrative components that are system-creating for environmental competence: readiness to make environmentally sound decisions and take responsibility for their own activities in the environment [10, p. 41-42].

N. Baiurko considers the readiness of the future biology teachers to form the ecocompetence of the pupils of the main school as a united characteristic of students. She distinguishes the functioning of axiological-motivational, knowledge-informational and technological-reflexive components in its structure [11].

Ya. Lohvinova offers a three-component structure of ecological competence of the future biology teacher for consideration. The scientist sees it as a set of correlations of such components as: value-motivational, cognitive, activity. At the same time Ya. Lohvinova is persuaded that «the cognitive component is a basis of responsible person's attitude to nature, ecological thinking, practical skills of ecologically appropriate behaviour in the system «human-nature», motivation and active participation in environmental activities, awareness of the involvement in the preservation, reproduction and protection of the environment» [12, p. 39].

I. Koreneva, S. Rudyshyn, V. Samilyk claim that value orientations, motivation and responsibility for the own behavior play a great role while formation of ecological competence of the future biology teachers. Therefore, scientists structurally fill ecocompetence with the following components: cognitive, value-motivational, activitypractical [13]. We completely agree and extrapolate the opinion of I. Koreneva to the ecological competence that the isolated components are formed and function on two interrelated levels: personal and professional [14].

Based on the own teaching experience, content filling, functional meanings of the future biology teachers' ecological competence in the process of analysis we outline the following components: knowledge-content, motivational-valuable, activitytechnological, professional-reflexive. 
We consider the knowledge-content component of the future biology teachers' ecological competence as a set of natural-scientific, psychological-pedagogical ecological knowledge, which is the basis of ecological worldview, understanding of natural-scientific picture of the world, essence and methods of ecological education, as well as the ability to master, operate with this knowledge and apply it in everyday life and professional activity. The content of this knowledge is generalised in Table 1.

Table 1. Content of knowledge of the knowledge-content component of ecological competence of future biology teachers

\begin{tabular}{|c|l|}
\hline Type of Knowledge & \multicolumn{1}{|c|}{ Meaning } \\
\hline $\begin{array}{c}\text { Natural Science } \\
\text { Knowledge }\end{array}$ & $\begin{array}{l}\text { Representation of natural science picture of the world, knowledge of } \\
\text { the universal laws of nature, nature-appropriate systemic principles } \\
\text { of building life. }\end{array}$ \\
\hline $\begin{array}{c}\text { Psychological and } \\
\text { Pedagogical Knowledge }\end{array}$ & $\begin{array}{l}\text { Knowledge of age features, psychological patterns and mechanisms } \\
\text { of student development in the conditions of educational process, the } \\
\text { basics of teaching skills, organizational forms, methods and } \\
\text { techniques of implementation of environmental education of } \\
\text { applicants general secondary education. }\end{array}$ \\
\hline Ecological Knowledge & $\begin{array}{l}\text { Knowledge of basic environmental concepts, laws and patterns, } \\
\text { features of human interaction and nature, the basics of environmental } \\
\text { safety, legal basics of protection and rational use of natural resources, } \\
\text { sustainable development of man and nature. }\end{array}$ \\
\hline
\end{tabular}

Not only the content of the knowledge but its quality as well plays a great role in the process of eco-competence formation of the future biology teachers. The quality has a number of indicators that are expressed, first of all, by completeness, generalization and systematization on the subject-content level.

The basis of ecological knowledge should be understanding nature as the highest value that will promote the formation of life and value orientations of man, in particular, a responsible and humane attitude to both nature and man [15, p. 3]. This knowledge is a specific form of unity of the sciences that study the complex relationship of man with the environment. The basis for the formation of this knowledge is the integrative processes that occur in modern science: generalization, consolidation and unification of different knowledge, the growth of their information capacity. Ecological knowledge is characterized by correlations between knowledge that create it: interaction, interaction, interconnections, interpenetration, mutual enrichment [16, p. 13-14].

We consider value-motivational component of ecological competence of future biology teachers as a set of values, motives, interests, needs that determine the attitude of students to nature, awareness of their role in the natural environment, personal involvement in solving environmental problems, environmental strategy, professional behavior and activities.

The value attitude to nature is formed in the process of ecological education and upbringing, it has the following characteristics: awareness of the functions of nature in human life and its self-worth; a sense of personal involvement in the preservation of 
natural resources, responsibility for them; the ability of the individual to coexist harmoniously with nature; competence behavior; critical assessment of consumerutilitarian attitude to nature, which leads to a violation of the natural balance, exacerbation of the ecological crisis; the ability to resist such attitudes in accessible ways; active participation in practical environmental activities: implementation of environmental activities on their own initiative; feasible environmental education [17, p. 152].

Ecological needs play an important role in the process of forming students' ecological competence: knowledge, preservation of the natural environment, communication with nature, implementation of ecological activities, dissemination of ecological knowledge, development of ecological culture of students, etc. The needs are the basis for the formation of the motives of ecological activity. Motives as internal forces for action activate the cognitive activity of future teachers, stimulate interest in ecological and pedagogical activities, show a desire to apply the acquired ecological knowledge in practice, encourage active ecological activity. Having taken M. Veber's classification as a basis, Ya. Lohvinova proposed to distinguish traditional, affective, value-rational and whole-rational motives of future biology teachers [12].

L. Tytarenko defines two stages of motivation in the process of ecological competence formation of students of pedagogical universities. We agree with the scientist that the first stage is characterized by motivation to encourage future teachers to increase the level of their environmental education and competence (motives of selfeducation, cognitive professional and value motives). Motivation to choose environmentally friendly activities in the environment, behavioral options that cause the least possible damage to nature (motives for nature conservation, universal value of nature) are the features of the second stage [10, p. 34].

The activity-technological component plays an integrative role in the structure of ecological competence of future biology teachers. It is a kind of indicator of the level of professional knowledge, professional orientation of applicants for higher pedagogical education, the level of environmental competence.

This component of students' eco-competence is focused on the application of knowledge in life and professional activity, on the development of intellectual and practical skills in the process of performing various types of cognitive activities, in the process of active participation in practical, seminar and laboratory classes, pedagogical practice, writing scientific research [14, p. 113].

The technological component of this component involves mastery of methods and techniques for the development of environmental competence of students of general secondary education. The activity-technological component of the studied quality contains the following skills of future biology teachers: to assess the current ecological situation, to carry out safe ecological activities (professional and domestic), to follow the rules of behavior in nature, rational use of nature and nature protection, to solve educational ecological problems, to use pedagogical techniques for the formation and the development of students' environmental competence.

Professional-reflexive component. After a person's acceptance of the values of natural objects on the basis of formed motives, reflection plays an important role. 
Reflection is the ability of a person to perceive himself with other eyes, as if from the outside, as well as self-observation and correlate their actions and deeds with universal norms which is manifested in feelings of pity, empathy, the desire to help not only other people but also natural objects [17, p. 164].

Yu. Boichuk outlines a special pedagogical type of reflection. The researcher defines a pedagogical reflection as a «teacher's awareness of himself as a subject of activity: his own characteristics, abilities, how he is perceived by students, parents, colleagues, administration. At the same time, it is the awareness of the goals and structure of one's activity, the means of its optimization» [16, p. 15-16].

To sum it up, we consider the professional-reflective component of environmental competence as the ability to consciously control the results of their professional activities in environmental education of students, the ability to self-knowledge and selfdevelopment.

Discussion. Summarizing the analysis of the specified problem allows to reach a conclusion that nowadays there is no unified approach to determining the structure of the ecological competence, it is dynamic. Most often scientists distinguish between cognitive, value-motivational and activity components. Regarding the name and content filling the rest of components vary depending on the context of the scientist's consideration of the problem, the author's vision of the research concept, etc. The results obtained during the structural-functional analysis of ecological competencies, in comparison with the previously mentioned works of other researchers, relate to the clarification of the structural and functional components of eco-competence of the future biology teachers': knowledge-content, motivational-valuable, activitytechnological, professional-reflexive.

Conclusions. In the end, we may claim that the ecological competence of future biology teachers as a complex structure is the result of their professional training. Ecological knowledge, skills, values, needs and motives, activities and behavior in the natural environment, awareness of the results of their own professional activities in environmental education of students, which corresponds to the knowledge-content, value-motivational, activity-technological and professional-reflexive components harmoniously combine and interact in the holistic structure of the studied competence. All these structural components of the studied phenomenon are in mutual unity and conditionality, permeated by functional connections. In the process of formation of eco-competence of future teacher`s it is necessary to take into account the content, functions, features of interaction of its components. Underestimation of any component will reduce the effectiveness of the molding action.

We connect the prospects of further scientific research in the chosen direction of research with studying the criteria, indicators and levels of formation of environmental competence of student's institutions of higher pedagogical education.

\section{References:}

1. Taranenko, H. H. (2010). Koevoliutsiina paradyhma u profesiinii pedahohichnii osviti [Coevolutionary paradigm in professional pedagogical education]. Naukovyi visnyk Melitopolskoho derzhavnoho pedahohichnoho universytetu, 4, 42-48 [in Ukrainian].

2. Khrolenko, M. V. (2018). Fakhova pidhotovka maibutnikh uchyteliv biolohii: kompetentnisnyi pidkhid [Professional training of future biology teachers: a competency approach]. Teoriia i metodyka profesiinoi osvity, 15. Retrieved from: 
https://e06d2b5d-7482-48f3-9eee-3163dd30a024.filesusr.com/ugd/2f377b_f9856da05faa4e5e9f7209ae24e179fc.pdf [in Ukrainian].

3. Crmakov, D. S. (2009). Pedagogicheskaya kontseptsiya formirovaniya ekologicheskoy kompetentnosti uchashchikhsya [Pedagogical concept of the formation of ecological competence of pupils]. Extended abstract of doctor's thesis. Moskva [in Russia].

4. Kurylenko, N. V. (2013). Poniattia pro ekolohichnu kompetentnist, yii strukturu ta umovy formuvannia u protsesi navchannia fizyky uchniv osnovnoi shkoly [The concept of environmental competence, its structure and conditions of formation in the process of teaching physics to primary school students]. Naukovyi chasopys Natsionalnoho pedahohichnoho universytetu imeni M. P. Drahomanova, 12, 30-38 [in Ukrainian].

5. Siaska, I. O. (2021). Teoretychni i metodychni zasady formuvannia ekolohichnoi kompetentnosti maibutnikh uchyteliv pryrodnychykh dystsyplin u protsesi profesiinoi pidhotovky [Theoretical and methodological principles of formation of ecological competence of future teachers of natural sciences in the process of professional training]. Doctor's thesis. Rivne [in Ukrainian].

6. Siaska, I. O. (2019). Struktura ta pokaznyky sformovanosti ekolohichnoi kompetentnosti maibutnikh uchyteliv pryrodnychykh dystsyplin [Structure and indicators of formation of ecological competence of future teachers of natural sciences]. Innovatsiina pedahohika,14 (1), 155-158 [in Ukrainian].

7. Nikitchenko, L. O. (2018). Formuvannia ekolohichnoi kompetentnosti maibutnikh uchyteliv pryrodnychykh dystsyplin u protsesi fakhovoi praktyky [Formation of ecological competence of future teachers of natural sciences in the process of professional practice]. Suchasni problemy biolohichnoi nauky ta metodyky yii vykladannia u zakladakh vyshchoi osvity, 5, 219-230 [in Ukrainian].

8. Lukianova, L. B. (2008). Suchasni pidkhody do formuvannia ekolohichnoi kompetentnosti fakhivtsiv [Modern approaches to the formation of environmental competence of specialists]. Suchasni informatsiini tekhnolohii ta innovatsiini metodyky navchannia $\mathrm{v}$ pidhotovtsi fakhivtsiv: metodolohiia, teoriia, dosvid, problemy, 17, 60-66 [in Ukrainian].

9. Shapran, Yu. P. (2015). Sutnisni oznaky, strukturni komponenty i vymiriuvannia ekolohichnoi kompetentnosti studentiv-biolohiv pedahohichnoho universytetu [Essential features, structural components and measurement of ecological competence of students-biologists of pedagogical university]. Pedahohichna osvita: teoriia i praktyka, 18, 320325 [in Ukrainian].

10. Tytarenko, L. M. (2007). Formuvannia ekolohichnoi kompetentnosti studentiv biolohichnyh spetsialnostei universytetu [Formation of ecological competence of students of biological specialties of the university:]. Candidate's thesis. Kyiv [in Ukrainian].

11. Baiurko, N. V. (2017). Pidhotovka maibutnikh uchyteliv biolohii do rozvytku ekolohichnoi kompetentnosti uchniv osnovnoi shkoly [Preparation of future biology teachers for the development of environmental competence of primary school students], Vinnytsia: TOV "Nilan LTD” [in Ukrainian].

12. Lohvinova, Ya. O. (2014). Formuvannia ekolohichnoi kompetentnosti maibutnoho vykladacha biolohii v protsesi vyvchennia pryrodnychykh dystsyplin [Formation of ecological competence of the future teacher of biology in the process of studying natural sciences]. Candidate's thesis. Kirovohrad [in Ukrainian].

13. Rudyshyn, S. D., Koreneva, I. M., Samilyk, V. I. (2016). Ekolohichna kompetentnist yak zahalna kompetentnist vchyteliv pryrodnychykh dystsyplin [Ecological competence as a general competence of teachers of natural sciences]. Ukrainskyi pedahohichnyi zhurnal, 3, 74-83 [in Ukrainian].

14. Koreneva, I. M. (2018). Zmist i struktura kompetentnosti maibutnikh uchyteliv biolohii u sferi osvity dlia staloho rozvytku [Content and structure of competence of future biology teachers in the field of education for sustainable development]. Ukrainskyi pedahohichnyi zhurnal, 3, 109-117 [in Ukrainian].

15. Anatska, N. V. (2016) Ekolohichna osvita: znannia i zhyttievo-tsinnisni oriientatsii suchasnoi liudyny [Ecological education: knowledge and life-value orientations of modern man]. Candidate's thesis. Kyiv [in Ukrainian].

16. Boichuk, Yu. D. (Ed.). (2014). Formuvannia ekoloho-valeolohichnoi kompetentnosti maibutnoho vchytelia u protsesi biolohichnoi pidhotovky: teoretyko-metodychni aspekty: metod. rekom. dlia vykl. ped. navch. Zakl [Formation of ecological and valeological competence of the future teacher in the process of biological training: theoretical and methodological aspects: method. rekom. to off. ped. textbook lock]. Kharkiv: KHNPU im. H. S. Skovorody [in Ukrainian].

17. Molchaniuk, O. V. (2020). Teoretyko-metodolohichni zasady vykhovannia v maibutnikh uchyteliv biolohii tsinnisnoho stavlennia do pryrody [Theoretical and methodological principles of education in future teachers of biology of values to nature]. Doctor's thesis. Kyiv [in Ukrainian]. 